\title{
The Importance of Art-Based Curriculum in Peace Education
}

\author{
Mahin Barkhordari ${ }^{1}$, Hasanali Bakhtyar Nasrabadi ${ }^{2}$, Mohammad Hossein Heidari ${ }^{2}$ \& Mohammad Reza \\ Neyestani ${ }^{2}$ \\ ${ }^{1}$ Philosophy of Education, University of Isfahan, Isfahan, Iran \\ ${ }^{2}$ Faculty of Education and Psychology, University of Isfahan, Isfahan, Iran \\ Correspondence: Mohammad Hossein Heidari, Faculty of Education and Psychology, University of Isfahan, \\ Isfahan, Iran. Tel: 98-91-7715-6112. E-mail: m.heydari@edu.ui.ac.ir
}

Received: August 16, 2016

Accepted: November 5, 2016 Online Published: November 24, 2016

doi:10.5539/res.v8n4p220

URL: http://dx.doi.org/10.5539/res.v8n4p220

\begin{abstract}
The present study aimed to draw attentions toward the importance of art-based curriculum in peace education. Arts education can nurture humanitarian and peaceable children. However, arts education and its effect on developing ethical skills, compassion, sympathy and peace have been neglected in many societies. In this research, by analytical-descriptive method, the interaction between arts education and peace education has been explained. The main finding of this research is that Arts education through various methods including visual arts, performing arts, cinema, and music provides different methods for revolutionizing the mind. Therefore, the role of content mediation of art for understandability of the truth about peace could not be neglected. Art as content becomes the mediator for understanding and nurturing peace.
\end{abstract}

Keywords: art, peace, arts education, peace education, curriculum

\section{Introduction}

Since the beginning of human creation, humans have always tried to make their surroundings beautiful. This effort has been soothing as well as pleasant for them. Later, this human desire has been called "art". According to many scholars, finding a comprehensive definition for art isn't an easy task. Tolstoy said that Art is the arena for human activities and includes deliberate attempts to use certain outward and emotional signs to transmit their experiences to others (Tolstoy, 1985, p. 55). Art represents characteristics of a society that depicts differences and changes in cultures and civilizations. Art is the outcome of human thought system and their creative skills of illustration, therefore, art is a representative of the society in which it is formed (Abaci, 2013, p. 691).

The great importance of Art in human life drew the attention of educational systems. But in a long time, art couldn't enter to the core of education. In order to move the art from margins to the center of education, huge efforts have been needed. In the case of this target, educational systems may enjoy the advantages of art curriculums. Robinson (2000) investigated three basic issues to consolidate the position of art in a knowledge-oriented society: The first of which is the "curriculum". Needless to say that no one can state for sure that mathematics is more important than music and science plays a more significant role compared to arts and human sciences. Thus, they are all equally important. The second issue was to teach "educators". Arts education is a highly professional skill and is not an easy task to accomplish. In case arts are to be enjoyed, learners have to immerse themselves in them. The final issue is the "cooperation". Schools must not ever be managed exclusively by the state educational system. Countless cultural and art organizations are interested in cooperation with the educational system and promotion of artistic trainings (Kian \& Mehr-Mohammadi, 2013, p. 122). Another important point emphasizing the importance of using art as an intermediary for nurturing peace is that art can contribute to promoting peace-oriented thoughts; The intermediary that covers and goes beyond an artistic arena and concerns itself with the nature of art and aesthetics in all fields. Thus, arts curriculum for the sake of promoting peace is both the base and the intermediary. It covers both the educational method and content aiming to teach aesthetic and humanistic senses to the learners and improve their emotional intelligence. In other words, art is a key to promoting peace in young learners and can facilitate this promotion through emotional and communicative tools, methods and contents. 


\section{Review of the Related Literature}

In their analysis of experiences of female teachers arts education in primary schools, Zolfagharian and Kian (2014) qualitatively demonstrated that teachers believe that arts education plays an important role in recognizing internal and mental problems in children and discovering their special talents. Teachers did their best and tried to make up for the lack of funding and facilities by providing them with their needs. Art for the unapt and hyperactive children is also of great benefits. It can increase the speed of emotional skills, training creativity and social participation and help them gain a better understanding of traditions and Islamic and ethnic cultures. Constant investigation of the teachers' guidebook for the arts curriculum and evaluation of their teachers' performance along with getting their feedbacks and utilizing them in updating the content of those books could have significant effects.

In another study by Navab (2014), the relationship between art and moral education was logically elaborated and two main understandings were extracted. Murdoch outlines the first one and believes that art can remove all evil and replace them with merits for imagination gives the power to see and attend the truth and as a result, illusion as the source of evil is eliminated. This ends in a moral life for the human. The second understanding states that art is mixed with imagination, therefore, it discovers the truth and this discovery is by nature a merit and ends in moral life.

Sodagar et al. (2011) demonstrated that the plan to teach philosophical thinking to children is a plan intending to improve thinking skills in children. The pioneers of this plan used literature as the most suitable tool for communicating for children for its hidden functions and properties. However, novel alternatives have been introduced as well. The point here is that art as a substitute including literature is aided by various modern tools with internal content and has the potential to respond the fundamental, theoretical and practical position of art in thinking. Their paper considers art as a tool for attaining wisdom or thought and explains how this intermediary role in teaching philosophical thinking to children necessitates a theoretical approach and as a result aims to cultivate art and philosophical thinking as an integral obligation.

On the other hand, Saberi and Mahram (2011) showed that one of the major responsibilities of public education is to flourish artistic capacities in its learners. Art production, art criticism, aesthetics and the history of art as indices of arts education, music, drama and visual arts as the content structure of art books at schools and educational planners have to consider them in their plans to realize potentials in humans. In their paper conducted through content analysis, all the art books in the secondary school levels of Iran published in the school year 2008-2009 were selected as the corpus of the study. The recording unit was given to the text, image and the exercise. The coding was inductive and was done based on subjective and structural categories. The coding was validated by asking a second evaluator to code $10 \%$ of the content which led to $86 \%$ agreement. Their results revealed that aesthetics along with the history of art in Iran and Islam were respectively of the highest dimensions of arts education, painting, calligraphy and graphic and held the first to third ranks in the priorities of art books in the educational grades under study. Results also revealed that important aspects of art like music, drama, the history of world art and art criticism are the most neglected ones.

Marshall, Laurie (2014) in an article titled "Art as Peace Building" shows that Art educators can "critique" senseless violence-mistreatment, exclusion, intimidation, bullying, violation, abuse, corruption, murder, and war by unleashing the power of students' creativity. In this article, the author, sharing her philosophical context, discusses how art is preventative medicine with the power to transform the cycle of violence. She focuses on three realms: (1) Art healing the effects of violence on the individual; (2) Art unifying divisions within a school; and (3) Art for building peace in a greater community. The practice of art actually rewires the brain to move from "difference as danger" to "difference as richness". As our world increases in complexity, the arts have an increasingly vital role to play to set the stage where peace is possible and violence is prevented.

Gültekin (2013) believes that peace education embraces a wide range of ideas ranging from creating a peace literature on which international community agrees to developing unique and innovative models for peace. Artistic productivity is one of the main topics for peace education. In this study titled "Communication Models and Sensitivity Approaches for Intercultural Peace Education", peace education through the concept of sensitivity and the strong emphasis of art on peace education will be structured. Also communication efforts in educating the society through peace will be annotated through models and unique public relation activities. Techniques of molding a public opinion on Peace Education, civil society and media's role on educating the society, reinforcing the education with initiatives by artists, international organizations and educational institutions captaincy for peace, peace literature education, emphasizing on democracy through peace education and a strong call for democracy to world public opinion are other important topics on this subject. 
Another study by Orhuan Beykal (2009) demonstrated that achievements of each student obtained through various methods and combinations of them are equal opportunities for educational parameters. Direct reception method easily makes students tired and then they receive a lower level of knowledge. Visual art instructor can take an interactive approach toward students and nurture their humanistic and cooperative skills.

\section{Research Methodology}

The present study is a qualitative library research. It involves identifying and locating sources that provide factual information or personal/expert opinion on the research questions. This study aims to investigate the position of arts education in nurturing peace and philanthropist behavior through a multifaceted (description, analysis and documentation) and scientific approach. In this regard, the present study briefly reviews theoretical and philosophical principles of arts education and elaborates on the reasons for the importance of art and its humanistic position to discuss using art in peace-oriented curriculums. The authors have used domestic and foreign databases along with theoretical principles to investigate art and the position of arts education in nurturing peace.

\section{Research Questions}

(1) What is the role of art in peace education?

(2) What are the artistic teaching-learning techniques for nurturing peace?

(3) How does art curriculum mediate in nurturing and institutionalizing peace?

\section{Arts Education}

Considering the content of art curriculum, artistic production of the process of a reaction to observations, ideas, emotions and experiences through creating art works with high levels of wisdom and professionalism, imaginary application of devices and various techniques and media is of huge diversity. Artworks are the products created via interventions between artists and their purposes, concepts, approaches, cultures and social traditions together with other materials and media they select for their works (Getty cited in Wilson, 2002).

It could then be concluded that arts education is beyond teaching skills, activities and special knowledge to learners. Therefore, art curriculums have to improve workshop potentials and train teachers so that they cultivate their skills through working with teachers of other subjects and artists in different educational contexts. Art curriculum has to encourage the growth of knowledge and skill in the following areas:

- One or more fields of art

- Interdisciplinary forms of art

- Methods of arts education

- Methods of interdisciplinary teaching inside and through arts

- Curriculum design

- $\quad$ Evaluation relative to artistic education

- $\quad$ Official (school-based) art training

- Unofficial (society-based) art training

Thus, even in regional and national levels, instructions and standards have to be compiled so that arts teachers prepare themselves through trainings they receive before accepting their responsibility (World Conference of Arts Education, 2016). In fact, an incorporative approach provides students with problem solving opportunities through learning to create art and improve their skills in establishing meaningful relationships with art. Interdisciplinary or incorporative curriculums gives insight to students and encourages them to combine novel relationships between distractions (the National Arts Education Association, 2002; cited in Banga Chohkar, 2010, p. 142). Arts education is essential for the learners who yearn to be a perfect human and nurture themselves intellectually. Eisner (1972, p. 184) outlines the importance of arts education as follows:

- Arts education is a cognitive and intellectual necessity increasing cooperation, learning and creativity and preparing the individual to gain the ability to express themselves and select the proper path to cultivate his inherent aptitudes.

- Arts education as an individual necessity mandating aesthetic, cognitive, moral and emotional growth.

- Arts education as an efficient and productive necessity nurturing individual values and inducing participation in the process of production and creation of art. 
In order for arts education to realize its ideals, proper physical structure, competent educators and insightful learners seeking creation and flourishing are vital (Sahan, 2009, p. 986).

Wyse and Ferrari (2014), Aysel (2014), Sharafi and Slasabili (2014), Saberi et al. (2013), Kian and Mehr Mohammadi (2013) and Ghadami (2013) have all investigated innovations in arts curriculums of schools and universities and have proved the need for them.

\section{The Need for Arts Education in Nurturing Peace}

In a relatively comprehensive definition, peace is defined as a mental, social, political, moral and spiritual state demonstrated in individual, group and global levels of human life. The final outcome of these states is human transformation from being self-centered, selfish and aggressive with dual insider-outsider outlooks to a universal and knowledge oriented view toward fundamental unity of humans and the link between them and the whole life in its ultimate sense (Danish, p. 46).

Teaching peace is of such a vast range that can cover a child's aggression in school level, racial segregation in the national or international level and even global commitment to saving the planet. However, its basics vary form one community to another. Nevertheless, forms and contents of teaching peace coincide with the implicit and explicit understanding from background condition and the related affairs (Haulsrod \& Sternberg, 2012, p. 14). In spite of the fact that teaching peace may have various purposes, each society has a special technique for educating peace and is of a rich source of topics and discussions. Based on the wide variety of challenges facing humans, several ways are proposed for reaching security. Thus, teaching peace includes different forms and issues. Different forms of violence need different techniques of teaching peace.

One of the ways through which peace could be realized, is using art. Psychologists and art critics believe that having an artistic life guarantees salvation in social and individual life of people. Therefore, art helps solve mental disorders and increases internal coordination. This will be facilitated if we understand ourselves. This promotes mutual compassion and understanding and removes humans' introversion toward their fellow counterparts. On the other hand, this cements the accepted social values and promotes ethics. According to several scholars, peace plays the reliving role historically played by religion (Shabani \& Raki, n.d., p. 288).

Teaching peace and arts have several common purposes. They both aim to relieve stress, improve concentration, expand imagination and augment sympathy. Whenever words cease to work music begins. Whenever a fact, an incident or a human experience could not be expressed through verbal signs and philosophical, logical and scientific concepts, art begins. Art can do things that could not possibly be done with things that use verbal potentials of the language. It refers to human senses and when added to revelations, art demonstrates a high level of potential for transmitting inherent experiences of humans and reveals mysteries that could not ever be opened with any other keys. Art opens up routes for humans that could not be traversed with unstable feet of wisdom and logic. Artistic creation is of an elevated position in the spiritual life of humans and this gives it a higher position compared to science, logic and even philosophy (Ahmadi, 2013, pp. 1-2). The power of an image of a war-stricken kid is incomparable to hundreds of books and articles published to censure violence and praise peace.

Maxine Greene, in his book titled "releasing imagination: papers on education, art and social change" (1995), believes that imagination is the basis for educational and social reforms. Greene takes classes and societies into consideration that value multiple views, democratic pluralism, life stories and constant social changes. According to him, this could only be possible through artistic, literary and phenomenological experiences inducing the release of imagination. For him, arts education is a tool for stimulating learners' imagination, thinking in different ways, confronting others in an objective and in the form of a persona in a play or a novel and staying in a reality apart from real life conditions as a necessity for appreciating a work of art. Being inspired by descriptions of artistic interactions by John Dewey and other scholars, Greene introduces the formation of an artwork in the subconscious as a metaphor for the process of learning (Palmer, 2012, p. 213). Dewey on the other hand believes that art help us better understand others. Cordiality is not the outcome of the information we acquire about others, even though this information could be of some help to the continuation of these relationships. However, this could only happen if this information becomes an inseparable part of sympathy through imagination. Understanding others becomes feasible when interests, trends, desires and purposes of someone converge with one's own. We then learn to see through their eyes and hear through their ears and these are the outcomes of the real learning for they turn into parts of one's body. Teaching the art of life is beyond transmitting information about it. It is about communicating, sharing and participating in life values through imagination and artworks have the highest potential to help people share their art of life with others. Civilizations become crude as their individuals are divided into races, peoples, and groups with no 
communication between and lose the power of understanding each other (Dewey, 2012, p. 394). Contemporary art increases our understanding from current affairs. In case a relationship is established between beneficent and educational information available in elementary school books and stories, concepts, concerns, awareness and messages of artworks, positive thematic approach learning will be reached. Then a society will be founded by teachers and learners who are not only supervising their environment, but also actively confronting problems and attempting to solve them. This approach toward thematic learning finally promotes cordial and encouraging relationships via creating social participation and real life experiences.

\section{Philosophy of Arts Education}

\subsection{The Position of Arts Education}

Since the time Plato condemned art as the source of stupidity under the name of truth and expelled artists from his utopia to the present time in which art classes are given to math teachers to make up for the lack of time, art and artists have been neglected. However, this forced or sometimes willing seclusion has had its influence as a miraculous contribution to evolution of moral and spiritual affairs. In the history of the philosophy of art, two distinct philosophical groups are identified. Some believe that art must serve art or "Art for the sake of art". Art has an inherent gem and the artists create art for the sake of their own inherent and artistic joy.

The reason behind this version of art is to separate this form of artistic expression from social life. Such a theory believes that artists are not comfortable in a world full of class gaps. In this world, any form of human activity is dominated by business and market economy. According to this view, an original work of art could not justify any other thing but itself. The theorists behind the concept of art for art sake are generally the ones who oppose self-alienation in any form.

The other group believes that art is in a very close relationship with social affairs. For them, art is a tool for social communications and the artist is connected to the surrounding environment through his artwork. This artist criticizes, praises and is socially influential. Unlike the theorists of the first group, these theorists of the second group believe that the relationship between artistic creation and outside reality is always accepted for art beyond this relationship is nothing but mere regretful imagination. The only factor guaranteeing success of an artist, is the level at which he convinces people to believe him, understand his work and show reactions. Therefore, an artist cannot evade social values (ibid., p. 3).

Creating art, the artist can try things that have been deprived of him in his real life. This is beyond dos and don'ts. However, what does this freedom represent: the unification of the real world with the ideal one. The point worth mentioning here is that no branch of wisdom or human sciences can produce such experience. Humans are constantly facing the world emerging in front of them and their internal world. According to Shilling, in art, we can go through this distance and this is not done via wisdom but through artistic revelations and originality (Ahmadi, 2013, p. 341). Thus, understanding the relationship between art and collective life is of critical importance for in these relationships between art and social life a mutual interaction occurs successfully. On the one hand, the process of metal activity based on social experience and the concept of individual creativity in aesthetic innovation occurs and on the other hand the ability to appreciate this innovation and creating a relationship through suggesting concepts that could unify collective experiences of different groups and even the whole society happens (Dorinho, n.d., p. 74).

Dorinho believed that a work of art not only stimulates humans' praising emotions and feelings, but also the signs this product of imagination gives us. Then, humans seek to participate in a potential society which is completely far-fetched. The world is constantly recreating and is always reviving. Human imagination plays an important role in these ever-lasting revolution (ibid., p. 7). In fact, art and social life are two distinctively apart concepts converging at some pints. One is a creative spirituality and the other is the human civilization. This convergence helps to the understanding of an artistic experience inside a social experience (ibid., p. 4). Therefore, theorists of art as a social phenomenon consider it as an effective key for solving issues of the contemporary society.

Among all diverse cultures of the world, art has always sought spiritual and mental affairs and has opened up highways in these fields. Peace and seeking peace are two ways to seek the truth opened up by human art for the humankind. Thus, the concept of peace has always needed art for staying on the road to the truth. In fact, several techniques are utilized for teaching and promoting peace one of which is art. Various arts aim to transmit peace or violence in different ways. The fact that Plato sought censorship in poetry and music is a proof of social and political impacts of these arts (Dewey, 2012, pp. 84-284). Art may be a shelter to protect humans against calamities. Dante went through inferno. Homer related the story of the war of wars and Dostoyevsky outlined the darkness of human soul. Humans sought shelter in art and found it (Ahmadi, 2013, p. 502). 
Therefore, according to Greene, art can be the fundament of social reforms (Greene, 1995). Besides, art is one of the most exquisite ways to realize the true meaning of human. Children could use art to form efficient and positive concepts about humans and use it as a substitute for violent images in the media (Saheb Ghalam, n.d., p. 123). Art plays a key role in supporting learning and has the power to improve life skills, critical thinking, communication and their peaceful cohabitation (Corent, 1991, p. 5). In spite of vast impacts art has on human life, its education has remained inside conservative frameworks. Thus, the present paper aims to investigate the position of art in teaching and promoting peace for children. In order to do so, three major research questions are asked:

(1) What is the relationship between art and peace?

(2) How does art contribute to developing the culture of peace in children?

(3) What are the methods of teaching peace through art?

Accordingly, the paper gives a definition of art and aesthetics, and then goes on with practical suggestions on application of art and its distinctions. Later on, the relationship between art and peace is investigated. Finally, the method of teaching concepts related to peace to children is discussed.

\subsection{Aesthetics and Art}

One of the dialogues between Socrates and Hippias is about beauty. The last sentence Socrates says in this long conversation is "What is beautiful is difficult". Plotinus said, "Goodness and beauty are one and the same". According to Stendhal "Beauty is nothing other than the promise of happiness".

Before the mid nineteenth century, several philosophers attempted to elaborate on and define the concept of beauty. However, no final and clear definition could be given on beauty. In its modern definitions, beauty creates joy and apart from any benefit is senseless, public and turns into an endless goal (Ahmadi, 2012, p. 18). Shilling believed that the highest action wisdom has is the aesthetic one. The truth and goodness are unavailable unless in beauty, needless to say that aesthetic action is the same artistic revelation foe beauty is the unique concept introducing us to ourselves and is feed of and definition and determination (ibid., pp. 141-142).

Aesthetics in a broad sense includes humans' verve and sense when they face beauty. Although the aesthetic theory is humans' attempt to realize observations and senses in different artistic forms, it helps nurture humans with balanced and beautiful lives. In spite of the fact that aesthetic values are of a great position in arts courses, drama etc. they help cultivate the verve in common people as well (Gotec, n.d., p. 1).

The term art is usually differentiated from the term aesthetics. Aesthetics is a science talking about beauty of the nature and art. However, art and aesthetics are both one form of knowledge. Art is a form of knowledge referring to creation of the artwork and aesthetics is the appreciation of the beautiful (Khatami, 2008, pp. 11-12).

Art is part of the general concept of aesthetics and includes painting, calligraphy, architecture, performing arts, novels, poetry, music etc. The definition of art sometimes is so broad that covers the life style in the horizon of existence. When the "I" exists in the arena of existence, and existence keeps me in its arena, life of me will become poetic and artistic (ibid., p. 132).

In his book, "the birth of tragedy", Nietzsche states that "art makes life possible and worth of living". In response to those who considered art a degrading discussion for philosophers, he says, "I am sure that art is the topmost signification". He advised the world to be like a work of art that commences itself. The relationship between art and life had always been on Nietzsche's mind (Ahmadi, 2013, p. 81).

What we have taken as art should have the following characteristics:

(1) Art is a tangible product to be seen or heard. It could be either a material object like a book, sculpture or a $\mathrm{CD}$ or a performance like a play, a ballet or a concert. It could even be the finding of an individual.

(2) Art is of a communicative nature. Art as a cultural product is not merely an existence and has to have been seen, heard, touched or experienced. Thus, art is a communicative action. Whether the artist believes in this relationship or not and whether the artist wants it or not, art has a communicative function and could be demonstrated through a schematic plan.

$$
\text { Artist ------------------ Artwork ------------------- Audience }
$$

(3) Art is experienced for joy. This joy could be of different types. In order to have an aesthetic, recreational, interactive and mind-stimulating joy or even freedom, art could be utilized.

(4) Art is an expressive form. When it is linked to the real life, an interpretation or a story could be created. 
(5) Art is defined based on its background or its social or material context (Alexander, 2003, p. 3).

\section{Arts Education and Peace Curriculum}

Arts education has a significant effect on nurturing peace and philanthropist teachings in learners and especially at their early ages due to its human-oriented nature. Therefore, the most important elaborating factors of the relationship between arts curriculums and nurturing peace are listed as follows.

\subsection{Human-Oriented Nature of Arts Curriculums}

Education is basically an ethical affair and peace is an ethical value. Thus, the relationship between art, education and ethics should be elaborated on. Several discussions have been made on the relationship between ethics and art. Moralism in its most radical form limits the evaluation of an artwork to ethical criteria. Tolstoy is among these philosophers. He believes that "art has to stimulate brotherhood and philanthropist beliefs so that they become human instincts". For him, Christian art is the realization of brotherly unity of the human kind. Therefore, an art propagating segregation and separation in a society instead of unity and goodwill or turns into a joy for the few intellectuals of the society are not considered as good art (Bermodus, 2008, p. 13).

However, there is another group who separate art from moral affair and consider no relationship between these two phenomena. They even believe that many of the greatest works of art are not moral.

Another important approach taken by this paper is considering moral characteristics of a work of art. In this regard, an artwork is moral to the point that its artistic and aesthetic experience is negatively or positively effective (Kiran, 2001, p. 33). When moral characteristics of an artwork are aesthetically connected to it, the moral fault necessarily brings an aesthetic fault and moral good brings aesthetic good. Brisgut (1998, p. 281) expresses the moral position clearly as follows: "in case unpleasant moral traits are demonstrated, the aesthetic side will be faulty as well. In contrast, an artwork representing moral virtues will demonstrate an aesthetic beauty".

According to what was said before, the works of art with moral faults may sometimes be good or even masterpieces, yet, their faulty moralities will affects their aesthetic beauty. Thus, even though judging an artwork is not permissible merely through its morality, its close connection with the good and salvation of humankind will justify that judgment (Kumara, 2010, p. 5).

Therefore, for three simple reasons, our approach in this paper toward works of art is of moral nature. Firstly, our focus on education will be in its general sense and contradicts the immoral affairs. Secondly, our focus is on peace as an ideal and moral virtue with great value in social and individual life of humans. Thirdly, in our approach, art serves education and since children cannot make moral judgments and are not able to conduct critical thinking, not every type of art could be used in education.

\subsection{Peace-Oriented Properties Governing Arts Classes}

Learning is a social process. Beside family, schools are the earliest places in which children communicate with people. As an important part of their social life, children learn to react people with different ideas and make changes in themselves. Children learn to practice and adopt with diversity in their arts classes. One important issue worth being discussed in these classes is teaching peace.

Kaine and Caine emphasize on the necessity of students" access to "rational perception and crating the meaning imagined". Students share their life experiences through educational system. They discover problems, raise real questions and discuss their cooperation with others to create a world based on justice. The centerpiece of these styles of learning is artworks. Artists elevate our souls through their art and promote our awareness. They also balance the false images created by public media. If children have the needed knowledge for the background of the work of art and its reflection in the world covers children's concern and distresses, their understanding and thought will be stimulated (Kain \& Kain, 2013, p. 114). Children at their early ages are able to associate the stories, songs and anecdotes they hear from artists in their art artworks with their surroundings. Older children understand the motives behind cultural messages and not only resist them but also help others create novel and more different types. The important point here is that the world in a child's mind is governed by value and credit not by material property and offensive and instructive cultural traditions (Saheb Ghalam, n.d., p. 425).

The issues concerning peace should be discussed in two levels. The first one is the macro indexes and covers issues like poverty and violence. However, the second level necessitates more specific and more detailed cognitive understanding. Racial, cultural, gender, class, ethnic, religious, public institutions, and the civil society etc. are among these issues. 
Several techniques were traditionally used to teach social issues to children. These techniques were either child-centered or are related to various disciplines. Another more recent approach is the issue-based education. Teaching arts through issue-based technique is led through social, political and cultural frameworks and is mixed with other subjects to create a more balanced and more common teaching. Since various forms of art play a crucial role in combining whole and details, leaning and teaching important life skills, themes and concepts have to be supported so that activities like social sciences, mathematics, and verbal arts are balanced with visual arts, drama, music etc. (Cornett, 1999, p. 6).

Most teachers know that not all students will be professional artists in the future. However, they should be innovative and creative thinkers participating actively in a balanced and ideal society. As these students get older, teachers like them to be actively contributing life issues, make proper decisions for their lives and help optimize the society. Teachers wish to train students with the necessary knowledge for creating, pioneering and running the society. Studying art in a classroom through issue-based approach creates the possibility for educators and trainees to discuss their beliefs and ideas and discover solutions for their problems through acquiring knowledge. Visual arts also contribute to the preparation of the ground for these dialogues and their continuation. The issue-based approach in teaching arts enables students to study on subjects of peace and social issues and therefore they can develop criticizing skills and can interpret, create and review the visual culture surrounding them (Saheb Ghalam, n.d., p. 61).

Imagination plays a key role in arts classes. One of these roles is to let humans experience things from inside so that the worlds were common or an intimate commonality is created with the worlds or their creators. In these ways, things like transferring situations, e.g., painting, expressing feelings, e.g., music and both of them, e.g., pottery could be experienced (Eliot, n.d., p. 157). It should be noted that in an arts class for teaching peace, teachers and students do not aim to solve global conflicts but try to cover all about them. They use art to find creative ways to dominate the issues, ideas and problems. According to Staniszeweski, the most valuable artists of the contemporary world possess such a great insight that challenge us constantly so that our view toward world changes. Artists prepare our minds and thoughts for adopting new ideas (Staniszeweski, n.d., p. 289).

If education is to train active, responsible, socially creative and sensitive individuals to turn them into beneficent citizens, children have to participate in cultural affairs as critical learners. They should identify and collect their memories and life history, describe them artistically and challenge the presuppositions governing the atmosphere of education. The process of such transactions lets children understand the ever-changing character and structure of knowledge, protect it and reform it (Garoian, 1999, p. 84).

Arts classes develop the culture of peace and especially peace with the self and tranquility. Individuals learning art have more delicate souls and conduct fairer and more humane relationships. Very few painters or musicians use aggression to solve his everyday problems. Therefore, one of the major contributions of teaching arts to nurturing peace is that children can reach a higher tranquility through elevating children's humane spirit and providing them with an opportunity to release their feelings and internal problems. Moreover, leading an arts class toward teaching peace can increase peace seeking spirit and interest in peaceful relationships.

\section{Methods of Teaching-Learning Arts and Nurturing Peace}

Arts curriculums are based on experimental and practical approaches and prepare the ground for learners to benefit from aesthetic experiences and learn peace-oriented humanistic teachings. Some major teaching-learning methods in arts education are elaborated on here.

\subsection{Introducing Historical Sites via Active and Inquisitive Methods}

One of the methods of teaching peace to children is to introduce historical sites to them. This method utilizes buildings, regions, zones, structures and objects as documents of historical experience and cultural descriptions. Using this method, children can investigate historical and monumental buildings from distant past and discover their relationship with their environment. Furthermore, in this method, children learn how to protect historical sites and unique places. This method uses a background-behavioral approach. For instance, when someone looks at the Great Wall of China, she/he gets to know about the slavery and class system and can pursue the trend since those times into the present. In this method, memorial buildings and historical structures are considered as public art and investigated through peace-seeking approaches. Students learn peace with their environment and historical structures and attain hope and cordiality from museums and lives of the departed. When a teacher takes his students to the cemetery of veteran martyrs, according to McCarty (1995, p. 318), he does not praise war but commends those who sacrificed themselves to protect collective memories and lifestyles of the people in the territory. Moreover, these historical memorials do not induce regret but bring hope and reflect human challenges and tries for equality and liberty along with their sacrifice for their ideals. These memorials could teach 
selflessness, coalition and keeping promises and tell them to unite righteously for the good of the public (Hoffman, 1997, p. 55).

Another example could be the teacher taking his or her students to Khaneye Mashroote (the House of Constitution) and draws their attention to the individuals who did their best for equality, justice and legislation. In an arts class, students could be asked to collect images and data on historical sites and share them in their classroom via dialogues. In this dialogue-oriented education, unity and the atmosphere of respect and free speaking creates an atmosphere of class dialogues. These dialogues create a profound and meaningful relationship between students and teachers. When a student and his teacher participate in a logical discussion, and let the atmosphere of wisdom and thought govern the class, the outcome will be rich with thoughts and introspection (Neyestani, 2012, pp. 155-156).

\subsection{Dialogue and Telling Stories}

Teaching peace in a classroom could be done through the method of telling stories. Thinkers in the field of child art and literature believe that telling stories has historically been a method of education and has proven to be efficient in disclosing the problems teachers and students faced in their lives. This educational method in which the relationship between time and space along with story tellers and the listeners is profound produces a valuable moral and individual experience. Besides, in this method, the story teller and the listeners create a world based on words and imagination (Ghezel Ayaq, n.d., p. 15). Telling stories as an approach strengthening strategies provides those who share their stories with the opportunity to critically analyze their discourse and find new solutions using each other's ideas and experiences. The creative and critical story telling method of education is liberating and is also the base for the critical education (Saheb Ghalam, n.d., pp. 38-39).

\subsection{Creative Drama Method}

Through creative drama method, teachings of peace could be taught to children and turn it into an integral part of students' lives. This drama could be performed by students or conducted as a puppet show. Children face numerous ideas while performing these plays and with the help of images and other educational tools coupled with physical activities and explain themselves. Thus, students use drama to link their internal relations with their experiences inside and outside school (Saheb Ghalam, n.d., p. 141). Since creative drama is an enjoyable activity, teacher as a choice maker could practice the concept of peace with proper selection of stories. Furthermore, planning the play and dividing the tasks along with taking turns and mutual respect before and while performing the paly could intensify the spirit of peace and its related indexes.

\subsection{Application of Music as Mixture}

Using the limitless power of music in order to reach peace is also of vital importance. Music coordinates the five senses, improves internal order based on the principle of balance and beauty loving, and increases self-awareness, self-confidence and the feeling of self-value. Moreover, music expands the mindset of the child and effectively improve the spirit of teamwork, philanthropy, beauty-loving and positive thinking toward self and the universe. According to experiences in nursing schools, music positively influences the children with emotional and behavioral problems. In this regard, music prevents or decreases aggression, disobedience, irritation, anxiety, and mental phobias (Karimi, n.d., pp. 78-79). Besides, nurturing musical talents of children helps them better use harmony, coordination, rhythm, voice and value of tunes and forms their skills of listening, beauty, cordiality, balance and the holistic view to the world (ibid., p. 77). Thus, music could be used as a tool in arts classes. Music helps humans establish sound social relationships and peaceful life in the society. Music helps children and even adults find out about commonalities of different cultures and reach a deeper understanding about life (Salem, 2003, p. 18). In order to teach music to children, sounds of the nature including bird calls, wind, waterfall, trees and in whole the symphony of nature should be introduced to them (ibid., p. 36).

Other methods of improving peace skills in arts classes include painting, calligraphy, and pottery. Studying and teaching arts is a prolific interdisciplinary education available in the academic world for people of all levels ranging from kindergartens to universities and could contribute significantly to nurturing indexes of peace in educational system.

\section{Discussion and Conclusion}

According to these discussions, art for children and the things children do under the name of art has relationship with their benefit from awareness. In this regard, the common ground of art and childhood helps children become aware and revive the process of education without removing the childish philosophy as a result of mere abstract thinking. 
Besides, type of thought influenced by art and aesthetics of poetic or philosophical thinking facilitates peace-oriented thoughts. Arts education through various and vast methods of art including visual arts, performing arts, cinema, music and other forms of art applicable in architecture provides different methods for revolutionizing the mind. Therefore, the role of content mediation of art for understandability of the truth about peace could not be neglected for in this way, art as content becomes the mediator for understanding and nurturing peace. This can bring the truth to children's mind and tongue and make it accessible through various methods.

Furthermore, arts curriculum refers to emotional quality of discourse and practice. Then, practicing and artistic discourse in the process of art lets teachings of art emerge. As a result, without mediation of art in the process of education, moral and humane education of learners will be incomplete and without arts education, peace-oriented behavior will not have a chance to emerge. Arts education gives the opportunity to the society and the cultural environment to create novel meanings in the minds of leaners.

On the other hand, arts education's focus on centrality of human relations and the methods of creating and transferring meaning in the society institutionalizes it as an integral obligation. Society as a whole creates art and in a social process, art can intensify its mediating role in nurturing peace-oriented thoughts in children firstly as children and secondly as the future generation of the society.

Arts curriculum gives numerous opportunities to students so that apart from prescriptive and traditional methods and beyond limitations of the classroom communicate with the real world. Like language, art is of a multifaceted power in education which could function as a connecting device to enrich and link various aspects of human life. Primary school teachers' view toward arts is mostly a set of meaningless and repetitive activities. For them, art has no relationship with the lives of students and the education conducted at school. This reality that Art is used to pass time is a proof for lack of awareness about the potential power of art in primary schools. Issue-based arts education in a framework centered on social, political and cultural context could be guided in different ways, mixed with other subjects, taught combined with them and nurture peace.

Since arts education focuses on issues related to life and concerns of children, students are motivated to have a deeper look at themselves, other people and the surrounding environment. Teachers can get the help form their students and teach them how to investigate life issues artistically and creatively.

Another important characteristic dominating artistic activities is friendly cooperation and interaction. This is a vital factor in promoting peace. Dialogues among conducting artistic activities like painting, creative drama and artistic interpretation let the students know about deep relationship between art and society. Besides, students in these classes not only reach a new outlook about art but also they find themselves responsible agents for changing and reconstructing the diverse world. Peace forms in the personality of children and arts curriculum creates bravery. Then, the relationship between teacher and student with the most vital problems becomes an everyday one.

Formality in arts classes is much less than other classes and therefore, teachers can teach their students about tolerance, respecting other beliefs, various cultural and ethnic views, equality, and protecting the environment and institutionalize them. It should finally be noted that life without art may not endanger humankind but will sure make them poorer. It is hoped that the results from this study will help the officials in the ministry of education review curriculums through emphasizing arts curriculums and novel educational approaches for different grades especially the primary school years. This encourages schools and universities to enhance the standard in their art faculties. If officials and experts in the field of curriculums and arts education aim to train beneficent and philanthropist humans who love peace and nurture it in the society, school education and university could successfully do their responsibilities. It is hereby suggested that arts curriculums arts curriculums become integral to the curriculums in educational sciences and educational departments both qualitatively and quantitatively.

Moreover, school and university curriculums must take approaches with the help of students so that aesthetic and philanthropist potentials are learnt for social and artistic knowledge grows constantly in an orderly context. Students should learn that instead of memorizing facts they face in their everyday life they involve themselves. This could not be possible if cognitive, emotional, sentimental and mental and kinetic aspects are put together as the basis for arts curriculums. The present paper was the first step in identifying the need for arts curriculums in order to facilitate cordiality and peace in the society. These could be more applicable if teachers learn teaching methods, yet, this still has to be further investigated and planned carefully. It is also suggested that centers of curriculum planning and higher education universities analyze indexes of arts curriculum in different grades of 
schools. This helps them design a plan suitable for intellectual capacity of the students and is based on critical thinking. The result will be the arts course as an important course in educational centers.

\section{References}

Abasi, O. (2013). Concept education by art education and an investigation on the opinions of teacher candidates about the different concept. Procedia-Social and Behavioral Sciences, 690-695. http://dx.doi.org/10.1016/j.sbspro.2013.12.079

Ahmadi, B. (2013). The Truth and Beauty of the Philosophy of Art. Tehran: Markaz Pub.

Alexander, V. C. (2003). Sociology of the Arts. Rotledge.

Aysel, Y. (2014). As an Approach to Improving Creativity in Design Education. Art of Painting. Procedia-Social and Behavioral Sciences, 741-747. http://dx.doi.org/10.1016/j.sbspro.2014.05.130

Banga, C. K. (2010). Higher education and curriculum innovation for sustainable development in India. International Journal of Sustainability in Higher Education, 11(2), 141-152. http://dx.doi.org/10.1108/14676371011031865

Bar-Tal, D. (2002). The elusive nature of peace education. In G. Salomon, \& B. Nevo (Eds.), Peace Education: The Concept, Principles and Practice in the World (pp. 27-36). Mahwah, NJ: Lawrence Erlbaum.

Bermodes, J. L., \& Gardener, S. (2008). Art and Ethics. Tehran: Academy of Art.

Caine, R., \& Caine, G. (1997). Education on the Edge of Possibility. Association for Supervision and Curriculum Development.

Chambers, D. (2005). Telling Stories and Creative Drama. Tehran: Academic Publication Center.

Cornett, C. E. (1999). The Arts as Meaning Makers: Integrating Literature and the Arts throughout the Curriculum. Upper Saddle River, NJ: Prentice Hall.

Danesh, H. B. (2006). Towards an integrative theory of peace education. Journal of Peace Education, 3(1), 55-78. http://dx.doi.org/10.1080/17400200500532151

Dewey, J. (2012). Art as an Experience. Tehran: Qoqnoos.

Dovinio, J. (2011). Sociology of Art. Tehran: Markaz Pub.

Eisner, E. W. (1972). Educating Artistic Vision. US: Collier Macmilland Publishers.

Garoian. C. R. (1999). Performing Pedagogy: Toward an Art of Politics. Albany, NY: SUNY Press.

Gaut, B. (1998). The Ethical Criticism of Art. In L. Jerold (Ed.), Aesthetics and Ethic. Cambridge University press. http://dx.doi.org/10.1017/cbo9780511663888.007

Gerald, L. (2007). Philosophical Schools and Educational Thoughts. Tehran: SAMT.

Ghadami, M. (2013). Design-oriented education and its role in academic achievements of architecture students. Naghsh Jahan Semiannual, 4, 67-78.

Godalius, I., \& Spears, P. (2011). Contemporary Approaches in Arts Education. Tehran: Nazar Pub.

Gültekin, B., \& Tuba, G. (2013). Communication Models and Sensitivity Approaches for Intercultural Peace Education. Procedia-Social and Behavioral Sciences, 106(10), 641-650. http://dx.doi.org/10.1016/j.sbspro.2013.12.073

Haavelsrud, \& Stenberg. (2012). Analyzing peace pedagogies. Journal of Peace, 9(1), 65-80. http://dx.doi.org/10.1080/17400201.2012.657617

Hurst, P. H., \& White, P. (2006). The Philosophy of Education as the Principle Subject of Analysis Tradition. Mashhad: Publications of Firdausi University.

Karimi, A. A. (2002). Songs in Education. Abed Pub.

Khatami, M. (2008). Discussions on Phenomenology of Art. Tehran: Academy of Art.

Kian, M., \& Mehr, M. M. (2013). Identifying neglected aspects of arts curriculum in primary schools. The Semiannual Journal of Studies on Education and Learning, 3, 1-18.

Kieran, M. (2001). Indefence of the ethical evaluation of narrative art. British Journal of Aesthetics, 41, 26-38. $\mathrm{http} / / / \mathrm{dx}$.doi.org/10.1093/bjaesthetics/41.1.26

Kumaro, S. A. (2013). The Philosophy of Oriental and Christian art. Tehran: Academy of Art. 
Marshall, L. (2014). Art as Peace Building. Art Education, 67(3), 37-43.

Navab, S. M. H. (2014). The relationship between art and moral education from the point of view of Airis Murdoch. Kimiaye Honar, 17-26.

Neyestani, M. R. (2012). Principles of Dialogue: Methods of Recognition and Education. Isfahan: Amookhte Pub.

Orhun, B. F. (2009). Training \& Teaching Style in Accessing a Desired Classroom Discipline at Visual Art Courses. Procedia Social and Behavioral Sciences, 1, 692-696. http://dx.doi.org/10.1016/j.sbspro.2009.01.121

Palmer, J. A. (2012). The Fifty Modern Thinkers in Educational Sciences. Tehran: SAMT.

Saberi, R., Boorang, M., AKbari, S. F., Hussain, \& Ajam, A. A. (2013). Journal of Psychology and Educational Science, 131-150.

Saberi, R., \& Mahram, B. (2011). The position of artistic dimensions and content structure in art textbooks of secondary school: A new move to recognize the neglected curriculum. Journal of Educational Sciences, 61-82.

Sahan, M. (2009). A general evaluation of art education in Turkey. Procedia Social and Behavioral Sciences, 1(1), 984-987. http://dx.doi.org/10.1016/j.sbspro.2009.01.175

Salem, S., \& Mohammad, P. A. (2003). Teaching Music in Primary Schools. Monadi Tarbita.

Sharafi, H., \& Salsabili, N. (2014). Efficacy of learning opportunities in interaction between theory and practice in arts education. The Culture and Communication Studies Quarterly, 11, 72-96.

Sodagar, M. R., Dibaj, S. M., \& Islami, G. (2011). The need for mediation of art in teaching philosophical thinking to children. The Center for Studies in Human Sciences and Culture, 1, 25-50.

Tolstoy, L. (1985). What is Art? Tehran: Amir Kabir.

Wilson, S. (2002). Information Art. London and Masschusetts: MIT Press.

Wyse, D., \& Ferrari, A. (2014). Creativity and education: Comparing the national curricula of the states of the European Union and the United Kingdom. British Educational Research Journal, 2(4), 1-18.

Zolfagharian, M., \& Kian, M. (2014). Analyzing female teachers' experiencesin teaching arts in primary schools: A qualitative study. The Semiannual Journal of Theory and Practice in Curriculum, 4, 142-167.

\section{Copyrights}

Copyright for this article is retained by the author(s), with first publication rights granted to the journal.

This is an open-access article distributed under the terms and conditions of the Creative Commons Attribution license (http://creativecommons.org/licenses/by/4.0/). 